\title{
Use of fluorescent-based amplified fragment length polymorphism to resolve phylogenetic relationships of Colchicum species from Turkey
}

\author{
Ö. Karakaş Metin ${ }^{1}$, M. Türktaş², F. Ertuğrul ${ }^{1}$ and E. Kaya ${ }^{3}$ \\ ${ }^{1}$ TUBITAK Marmara Research Center, \\ Genetic Engineering and Biotechnology Institute, Gebze, Kocaeli, Turkey \\ ${ }^{2}$ Department of Biology, Faculty of Science, Cankırı Karatekin University, \\ Cankiri, Turkey \\ ${ }^{3}$ Atatürk Central Horticultural Research Institute, Yalova, Turkey \\ Corresponding author: Ö. Karakaş Metin \\ E-mail: ozge.karakas@tubitak.gov.tr
}

Genet. Mol. Res. 13 (1): 1480-1490 (2014)

Received August 7, 2013

Accepted January 10, 2014

Published March 6, 2014

DOI http://dx.doi.org/10.4238/2014.March.6.6

\begin{abstract}
The study of phylogenetic relationships between 14 Colchicum taxa spread throughout Turkey was performed using a fluorescent-based amplified fragment length polymorphism (AFLP) technique. Five primer pair combinations were used in AFLP reactions. The data set was analyzed statistically using the NTSYS 2.1 software, and the neighbor-joining and maximum parsimony methods were implemented to generate phylogenetic trees. These analyses clustered the samples into 3 main clades. Both the neighbor-joining and maximum parsimony analyses resulted in similar topologies. Furthermore, supporting the phylogenetic trees, a similar grouping of 14 taxa was generated by principal component analysis. The AFLP analysis with 5 primer combinations was carried out to assess 14 taxa. Fragment sizes ranged from 54 to 462 bp in length for each primer combination. The average was 166 fragments per primer pair,
\end{abstract}


primer B2 generated the highest number of bands (200), and primer B3 produced the lowest number of bands (112). A total of 834 polymorphic bands were scored. The cophenetic correlation coefficient between the data matrix and the cophenetic matrix for AFLP data was 0.72. Based on this molecular data, we concluded that the genetic diversity among these Turkish accessions is relatively high.

Key words: Colchicum; Amplified fragment length polymorphism; Phylogenetic relationship; Principal component analysis;

Neighbor-joining method; Maximum parsimony

\section{INTRODUCTION}

Colchicaceae is a family of flowering plants showing a widespread distribution. Africa, Asia, Eurasia, and North America are the natural habitats of the 19 genera (Vinnersten and Reeves, 2003). Because of the high frequencies of species and endemics, Turkey and the Balkans are the major centers of diversity and speciation (Persson, 1993). The genus Colchicum L. is represented by 39 taxa, of which, 18 are endemic to Turkey (Brickell, 1984; Persson, 2000, 2005, 2007; Akan and Satil, 2005; Düşen and Sümbül, 2007).

Colchicum species have been used as a medicinal plant for more than 3000 years (Franková et al., 2005). Modern medicine uses Colchicum as a source of therapeutically active alkaloids called colchicinoids. These are poisonous alkaloids and include colchicine (Baytop, 1999). Colchicine was isolated by Pelletier and Caventou in 1820. However, its complete structure was not determined until the 1950s (Goodman and Gilman, 1956). Geophytes are used not only in medicine but also in ornamental industries (Çelik et al., 2004). Many of them are grown in parks and gardens as ornamental plants because of their beautiful flowers.

Candolle was the first researcher to use the family name Colchicaceae in 1805 (Vinnersten and Reeves, 2003). Since then, the taxonomic status of several genera within Colchicaceae has remained uncertain (Kahraman and Celep, 2010). For instance, Colchicaceae often includes the genera Bulbocodium L. and Merendera Ramond. However, some authors separate 3 genera based on style and sepal characteristics (Kahraman and Celep, 2010). The subgeneric taxa of the genus Colchicum including a few genera such as Bulbocodium, Fouha, Merendera, Monocaryum, and Synsiphon were listed by Persson (2007). Anatomical features of different Colchicum species have been investigated several times (Akan and Eker, 2005; Persson, 2005; Düşen and Sümbül, 2007; Kahraman and Celep, 2010). Fridlender et al. (2002) studied genome size of the genus Colchicum using flow cytometry. Smith and Waldren (2010) used the amplified fragment length polymorphism (AFLP) genetic fingerprinting technique to clarify a question over the native status of the Irish Colchicum species to assess its conservation status by comparison with populations throughout northwestern Europe. Recently, Persson et al. (2011) used nucleotide sequences from 6 plastid regions and 33 morphological, life history, and chromosomal characteristics to identify phylogenetic relationships among Colchicum species. The trnL-trnF sequence of non-coding chloroplast DNA (cpDNA) is one of the most preferable regions to elucidate phylogenetic relationships among species. The phylogeny and classification of genera belonging to the Colchicaceae family was studied analyzing these regions (Vinnersten and Reeves, 2003; Türktaş et al., 2012). However, the power of this region fails to resolve the phylogenetic assessments (Després et al., 2003). AFLP emerges as an efficient technique to solve difficulties whereas cpDNA is not sufficient to identify phylogenies, particularly among 
closely related species or at the intraspecific level (Hodkinson et al., 2000; Koopman et al., 2001; $\mathrm{Xu}$ and Sun, 2001; Zhang et al., 2001; Karakaş et al., 2013). AFLP analysis can detect high levels of polymorphism and has high repeatability and speed of analysis. These markers have a quite high diversity index, resulting in a limited number of primer combinations that are required to screen an entire genome. In addition, they have been applied to develop a system for the fingerprinting of an organism (Faccioli et al., 1999) and for map expansion (Castiglioni et al., 1998).

In this study, we determined phylogenetic relationships between Colchicum species using AFLP markers. We discussed results of AFLP data to infer phylogenetic relationships among closely related species. The phylogeny was assessed with phenetic (neighbor-joining), maximum parsimony, and principal component analysis ( $\mathrm{PCoA})$ methods. The results are comparable with the previous phylogenetic studies for known Colchicum species. These data would be a valuable source for the taxonomy of Colchicum species distributed in Turkey, and it will supply further insights into the taxonomy of this complex genus.

In addition, the recently published Persson et al. (2011) report that inferred the phylogeny of almost all known Colchicum species based on sequence data of 6 plastid regions provided a phylogenetic hypothesis of the relationships within species in the genus. Nonetheless, because of the low resolution in some clades in the Persson et al. (2011) study, the inclusion of AFLP data in this manuscript will advance information to broaden the current understanding of Colchicum spp.

\section{MATERIAL AND METHODS}

\section{Plant materials}

Fourteen Colchicum taxa were randomly collected from natural wild populations that were found throughout Turkey (Figure 1). The assessment of phylogenetic relationships among C. dolichantherum, C. kotschyi, C. szovitsii, C. balansae, C. decaisnei, C. polyphyllum, C. cilicicum, C. inundatum, C. heldreichii, C. serpentinum, C. chalcedonicum ssp punctatum, C. macrophyllum, and C. speciosum was determined (Table 1).

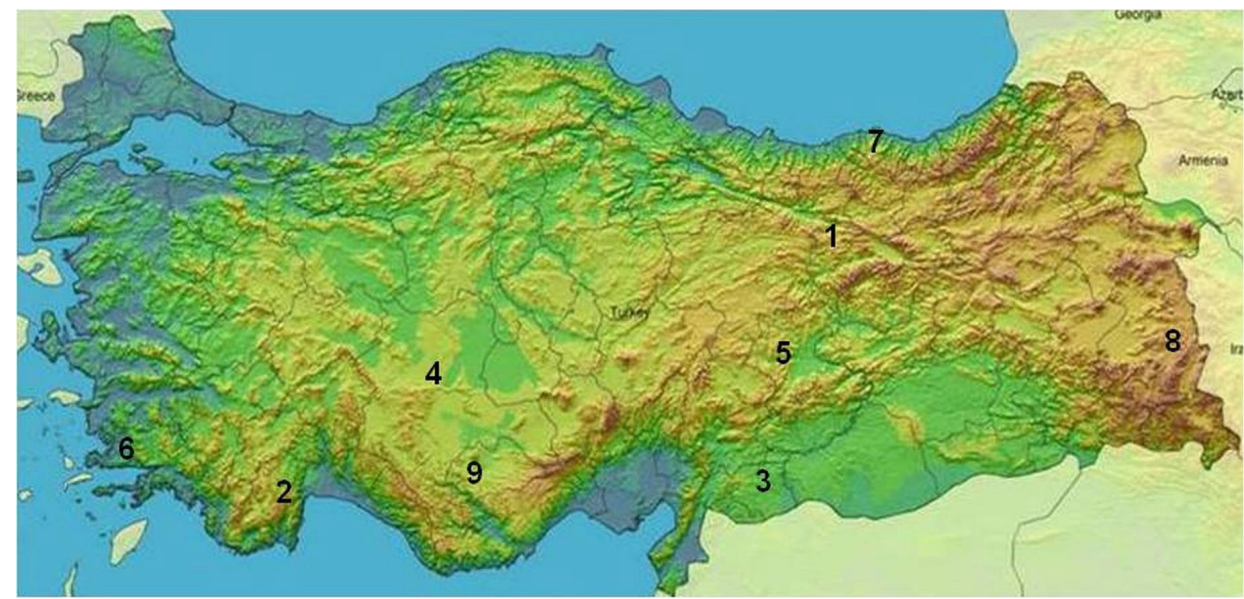

Figure 1. Approximate locations of collected materials in Turkey. Sites were pointed with numbers. Numbers correspond to samples as listed in Table 1. 
Table 1. List of the 14 Colchicum taxa analyzed, with voucher information and GenBank accession numbers of newly generated sequences.

\begin{tabular}{|c|c|c|c|c|}
\hline Colchicum species & $\begin{array}{l}\text { Place of collection } \\
\text { (Turkey) }\end{array}$ & Collector & $\begin{array}{l}\text { Collector } \\
\text { No. }\end{array}$ & $\begin{array}{l}\text { Accession } \\
\text { No. }\end{array}$ \\
\hline Colchicum decaisnei Boiss., Fl. Or. 5: 157 (1882) & Erzincan (1) & E. Kaya & CBT1 & JX012296 \\
\hline Colchicum dolichantherum K.M. Perss. in Edinb. J. Bot. 56: 126 (1999) & Antalya (2) & E. Kaya & CBT2 & JX012297 \\
\hline Colchicum polyphyllum Boiss. \& Heldr. in Boiss., Diagn. ser. 2, 4: 121 (1859) & Gaziantep (3) & E. Kaya & СВT3 & JX012298 \\
\hline Colchicum szovitsii Fisch. \& C.A. Mey. in Ind. Sem. Horti Petrop. 1: 24 (1835) & Konya (4) & E. Kaya & CBT5 & JX012299 \\
\hline Colchicum inundatum K.M. Perss. in Edinb. J. Bot.56: 99 (1999) & Konya (4) & E. Kaya & CBT6 & JX012300 \\
\hline Colchicum heldreichii K.M. Perss. in Edinb. J. Bot. 56: 98 (1999) & Konya (4) & E. Kaya & CBT7 & JX012301 \\
\hline Colchicum serpentinum Woron. ex Miscz. Fl. Caue. Crit. 2: 114 (1912) (a) & Malatya (5) & E. Kaya & CBT8 & JX012302 \\
\hline Colchicum balansae Planchon in Ann. Sci. Nat. Ser. 4, 4: 145 (1855) (a) & Muğla (6) & E. Kaya & CBT9 & JX012303 \\
\hline $\begin{array}{l}\text { Colchicum chalcedonicum subsp punctatum K.M. Perss. } \\
\text { in Candollea 53: } 405 \text { (1998) }\end{array}$ & Muğla (6) & E. Kaya & CBT10 & JX012304 \\
\hline Colchicum macrophyllum B.L. Burtt in Kew Bull. 5: 433 (1951) & Muğ & E. Ka & CBT11 & JX012305 \\
\hline Colchicum speciosum Steven in Nouv. Mèm. Soc. Imp. Mosc. 1: 265 (1829) & Trabzon (7) & E. Kaya & CBT12 & JX012306 \\
\hline Colchicum kotschyi Boiss., Diagn. ser. 1 (13): 38 (1853) & $\operatorname{Van}(8)$ & E. Kaya & CBT13 & JX012307 \\
\hline Colchicum serpentinum Woron. ex Miscz. Fl. Caue. Crit. 2: 114 (1912) (b) & Karaman (9) & E. Kaya & CBT14 & JX012308 \\
\hline Colchicum balansae Planchon in Ann. Sci. Nat. Ser.4, 4:145 (1855) (b) & Karaman (9) & E. Kaya & CBT15 & JX012309 \\
\hline
\end{tabular}

\section{DNA isolation}

Total genomic DNA was isolated using the cetyltrimethylammonium bromide extraction method modified from Doyle and Doyle (1990) by washing the DNA pellet in 70\% ethanol and suspending it in nuclease-free water. Each genomic DNA was diluted to $100 \mathrm{ng} / \mu \mathrm{L}$ with nuclease-free water. DNA samples were quantified using the Nanodrop ND-1000 spectrophotometer. In addition to that, their qualities were evaluated by electrophoresis on $0.8 \%$ agarose gels according to Sambrook et al. (1989).

\section{AFLP analysis}

AFLP fingerprints were generated using adaptors and fluorescently labeled primers from the AFLP Amplification Core Mix Module Analysis (Applied Biosystems, CA, USA) based on manufacturer instructions. Briefly, enzyme master mix was prepared to perform the restriction-ligation reactions for a DNA sample using 10X T4 DNA Ligase Buffer, 0.5 M $\mathrm{NaCl}, 1 \mathrm{mg} / \mathrm{mL}$ bovine serum albumin (BSA), $1 \mathrm{U}$ MseI, $25 \mathrm{U}$ EcoRI, and $2 \mathrm{U}$ T4 DNA Ligase. The restriction-ligation reactions created the template for adaptors. Then, adaptor pairs were ligated to the prepared template DNA. DNA digestion was carried out using EcoRI and MseI (BioLabs, MA, USA); $0.5 \mu \mathrm{g}$ genomic DNA was added to a reaction mixture containing 10X T4 DNA ligase buffer that included ATP, $1 \mathrm{mg} / \mathrm{mL}$ BSA, $5 \mu \mathrm{M}$ EcoRI adaptor, $50 \mu \mathrm{M}$ MseI adaptor, $1 \mu \mathrm{L}$ enzyme master mix, and water to a final volume of $10 \mu \mathrm{L}$. After incubation for $2 \mathrm{~h}$ at $37^{\circ} \mathrm{C}, 189 \mu \mathrm{L} \mathrm{TE}_{0.1}$ buffer $[20 \mathrm{mM}$ Tris- $\mathrm{HCl}, 0.1 \mathrm{mM}$ ethylenediaminetetraacetic acid (EDTA)], pH 8.0 was added to each restriction-ligation reaction. The DNA template that was prepared by restriction-ligation was diluted 20 -fold with $\mathrm{TE}_{0.1}$ buffer, and about $4 \mu \mathrm{L}$ DNA template was amplified in a final volume of $20 \mu \mathrm{L}$ in a mixture containing AFLP Core Mix (Applied Biosystems, CA, USA) and $1 \mu \mathrm{L}$ AFLP pre-selective primer pairs. The polymerase chain reaction (PCR) was performed with the following program: 2 min at $72^{\circ} \mathrm{C} ; 30$ cycles of $30 \mathrm{~s}$ at $94^{\circ} \mathrm{C}, 30 \mathrm{~s}$ at $56^{\circ} \mathrm{C}$, and $2 \mathrm{~min}$ at $72^{\circ} \mathrm{C}$; and $10 \mathrm{~min}$ at $60^{\circ} \mathrm{C}$. The presence of the pre-amplified products was verified through electrophoresis on a $1.5 \%$ agarose gel in $1 \mathrm{X}$ Tris, 
boric acid, EDTA buffer. Pre-selective PCR amplification products were 20-fold diluted with $\mathrm{TE}_{0.1}$ buffer. The selective amplifications were carried out using 5 primer pair combinations [EcoRI AGG*D4-MseI CAA (B2), EcoRI AGG*D4-MseI CTT (B3), EcoRI AGG*D4-MseI CAT (B8), EcoRI AGG*D4-MseI CAC (B9), and EcoRI AGG*D4-MseI CCA (B10)], which were selected on the basis of the quality and quantity of bands produced. These were used in AFLP reactions on all 14 samples. The PCR mixture was the same as the pre-amplification reaction, except for the primers [MseI (Primer-Cxx) at $5 \mu \mathrm{m}$ and $1.0 \mu \mathrm{L}$ EcoRI (Dye-primerAxx) at $1 \mu \mathrm{M}]$. The amplification program was: 1 cycle at $94^{\circ} \mathrm{C}$ for $2 \mathrm{~min} ; 13$ cycles of 30 $\mathrm{s}$ at $94^{\circ} \mathrm{C}, 30 \mathrm{~s}$ ramping from 65 to $56^{\circ} \mathrm{C}\left(0.7^{\circ} \mathrm{C}\right.$ per cycle $)$, and 1 min at $72^{\circ} \mathrm{C} ; 24$ cycles of $30 \mathrm{~s}$ at $94^{\circ} \mathrm{C}, 30 \mathrm{~s}$ at $56^{\circ} \mathrm{C}$, and $1 \mathrm{~min}$ at $72^{\circ} \mathrm{C}$; and 1 cycle at $60^{\circ} \mathrm{C}$ for $30 \mathrm{~min}$. About $2.5 \mu \mathrm{L}$ amplification product was added to $17.5 \mu \mathrm{L}$ sample loading solution mixed with the DNA size standard-400 and overlaid with mineral oil. AFLP detection via capillary electrophoresis was performed using fluorescently labeled primers. Fluorescently labeled final PCR products were separated, detected, and precisely quantified by the GeXP system. The separation conditions on the GeXP system were as follows: capillary temperature $50^{\circ} \mathrm{C}$, denaturation at $90^{\circ} \mathrm{C}$ for 120 $\mathrm{s}$, injection for $30 \mathrm{~s}$ at $2.0 \mathrm{kV}$, and separation at $6.0 \mathrm{kV}$ for $35 \mathrm{~min}$.

\section{Data scoring and statistical analysis}

Each PCR product was assumed to represent a single locus, and only reproducible polymorphic bands were scored automatically by the GeXP system as present (1) or absent (0). All fragments were given equal weights. Only fragments between 54 and 462 bp were taken into account to avoid scoring problems due to excess primer peaks near the front of the electrophoresed fragments and a decreasing signal for fragments longer than $500 \mathrm{bp}$.

Neighbor-joining (NJ) and maximum parsimony (MP) methods were implemented for phylogenetic analyses. MP analysis was conducted with the Phylip v.3.69 software (Felsenstein, 1989). MP trees were built using the Fitch (1971) method. The level of support for branches was tested using bootstrap analysis with 1000 replicates (Felsenstein, 1985). The NJ analysis was performed utilizing the Phylip v.3.69 software, and it was conducted by calculating Kimura's (1980) 2-parameter distance. The binary matrix of AFLP data was converted to a distance matrix using the PhylTools package (Buntjer, 1997). Genetic similarities among samples were calculated using the Jaccard similarity index. A phylogenetic tree was generated using the NJ method of Saitou and Nei (1987) and implemented by the Phylip v.3.69 software (Felsenstein, 1989). Trees were viewed with the Tree View v.32 program (Page, 1996).

The Mantel test (Mantel, 1967) with the random permutation number of 1000 was performed to determine the extent of distortion from converting the data into the dendrogram by comparing the original similarity matrix with the cophenetic value matrix that was calculated from the AFLP dendrogram. PCoA was carried out using NTSYS-pc package version 2.1 (Rohlf, 2000). In addition, the samples were plotted as points in a 3-dimensional continuous space.

\section{RESULTS}

\section{AFLP primer combination evaluation and AFLP divergence}

The AFLP analysis with 5 primer combinations was carried out to assess 14 taxa. Fragment sizes ranged from 54 to $462 \mathrm{bp}$ in length for each primer combination (Table 2). The average was 
166 fragments per primer pair, primer B2 generated the highest number of bands (200), and primer B3 produced the lowest number of bands (112). A total of 834 polymorphic bands were scored.

Table 2. Statistics of fragments generated by each amplified fragment length polymorphism primer pair.

\begin{tabular}{lcccc}
\hline Primer pair combinations & Primer pair code & Minimum fragment length (bp) & Maximum fragment length (bp) & No. of fragments \\
\hline EcoRI AGG*D4-MseI CAA & B2 & 54.15 & 461.88 & 200 \\
EcoRI AGG*D4-MseI CTT & B3 & 54.28 & 447.08 & 112 \\
EcoRI AGG*D4-MseI CAT & B8 & 54.19 & 454.15 & 172 \\
$E c o$ RI AGG*D4-MseI CAC & B9 & 54.27 & 460.05 & 173 \\
$E c o$ RI AGG*D4-MseI CCA & B10 & 54.19 & 458.67 & 177 \\
Total & & & & 834 \\
\hline
\end{tabular}

The genetic relationships between samples were investigated using PCoA. The first 2 axes accounted for $28.26 \%$ of the variation in the dataset, and their eigenvectors were plotted in Figure 2. The first axis accounted for $19.24 \%$ of the variation in the whole dataset, and the second axis accounted for $9.01 \%$ of the variation.

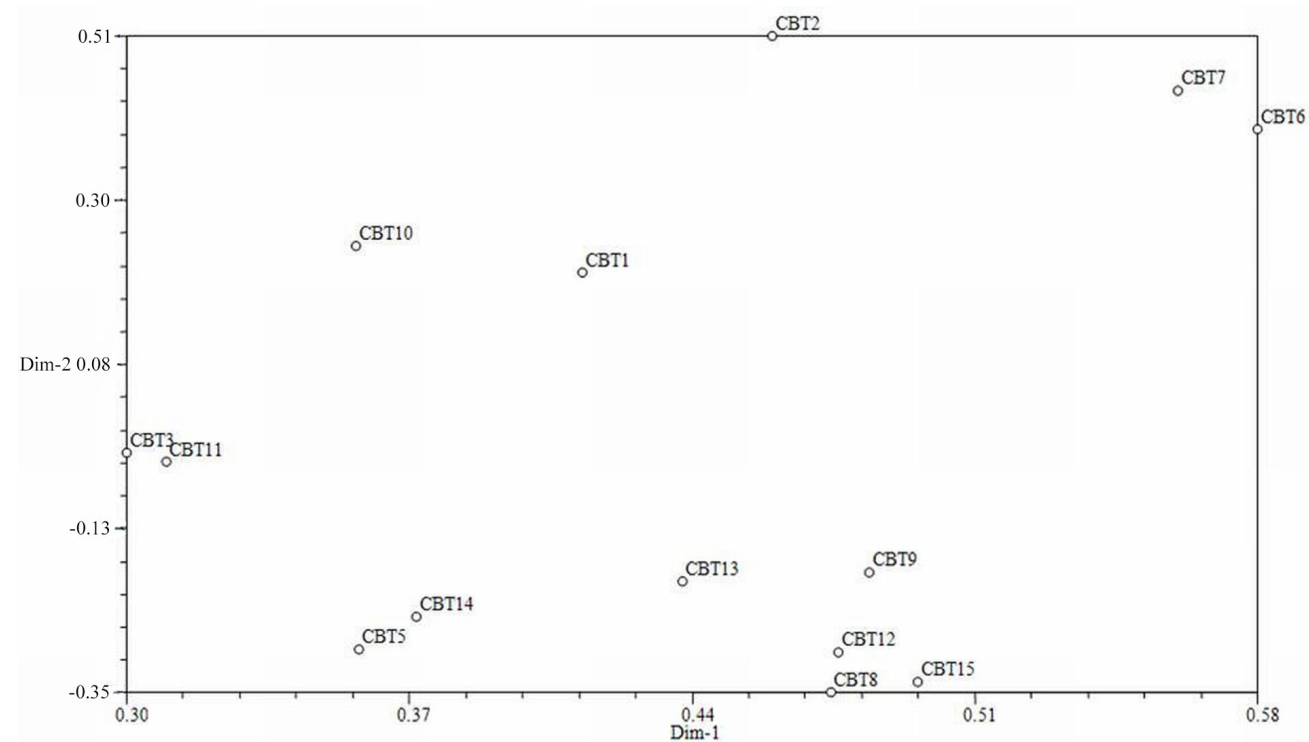

Figure 2. Plot of first two axes from a principal coordinates analysis. Axis 1(Dim-1) accounts for 19.24\% of the variation in the dataset, and axis 2 (Dim-2) accounts for $9.01 \%$. The numbers correspond to individuals as indicated: 1) C. decaisnei, 2) C. dolichantherum, 3) C. polyphyllum, 4) C. szovitsii, 5) C. inundatum, 6) C. heldreichii, 7) C. serpentinum (a), 8) C. balansae (a), 9) C. chalcedonicum subsp punctatum, 10) C. macrophyllum, 11) C. speciosum, 12) C. kotschyi, 13) C. serpentinum (b), 14) C. balansae (b).

The species were divided into 3 groups by PCoA (Figure 2). The cophenetic correlation coefficient (r-value) between the data matrix and the cophenetic matrix for AFLP data was 0.72.

The NJ tree based on AFLP data identified 3 main groups (Figure 3). C. balansae (CBT15) and C. balansae (CBT9) generated clade 1. The second clade was formed by $10 \mathrm{Col}$ chicum species. Two of the C. serpentinum isolates (CBT14 and CBT8) were collected from different regions in Turkey and formed the second clade with C. macrophyllum, C. chalce- 
donicum subsp punctatum, C. dolichantherum, C. inundatum, C. heldreichii, C. polyphyllum, and $C$. decaisnei. The last group included only C. kotschyi and C. speciosum.

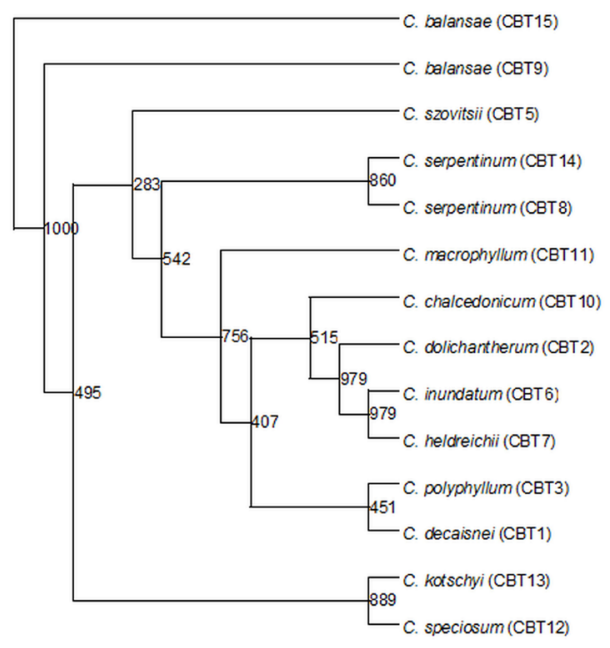

Figure 3. Neighbor-joining tree based on AFLP data.

The MP tree revealed that 3 major clades arose among the samples, and clade 2 was further divided into 2 subgroups (Figure 4). C. balansae (CBT9 and CBT15) and C. szovitsii comprised clade 1. Colchicum serpentinum (CBT14 and CBT8) and C. macrophyllum formed the first subgroup of clade 2. C. polyphyllum, C. chalcedonicum subsp punctatum, C. decaisnei, $C$. dolichantherum, $C$. heldreichii, and $C$. inundatum created the second subgroup of clade 2 MP analysis. The last group included C. speciosum and C. kotschyi.

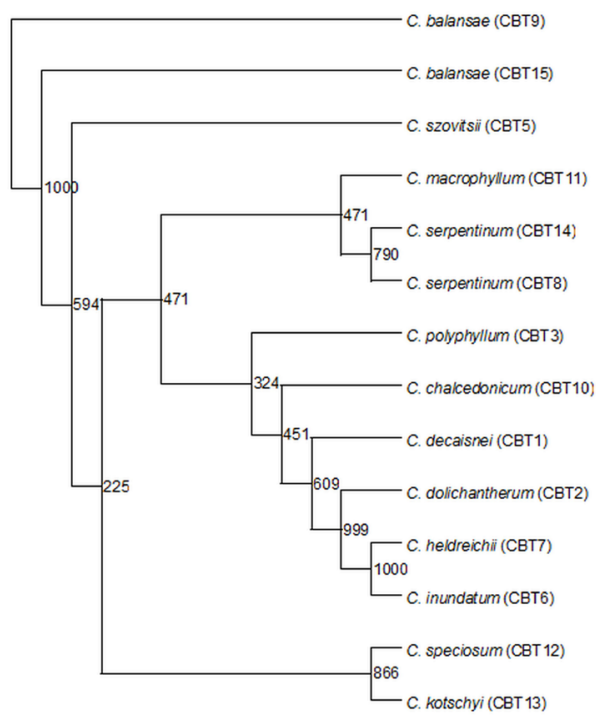

Figure 4. Maximum Parsimony tree based on AFLP data. 


\section{DISCUSSION}

Phylogenetic relationships within the genus Colchicum L. have been studied several times since Baker's original report (1879). Because of the high morphological uniformity and low number of diagnostic characteristics among species, the phylogeny of the genus has always been a matter of question (Persson et al., 2011).

As a result of random sorting of polymorphic alleles in different lineages, gene trees do not always correspond to the true phylogeny of species (Després et al., 2003). The advantages of the AFLP technique can be observed in the large number of fragments that are revealed and the highly reproducible results. In addition to a similar accuracy degree of AFLP and sequence data, AFLP showed higher resolution (Althoff et al., 2007; García-Pereira et al., 2010). Therefore, in this study, AFLP was applied to obtain accurate phylogenetic relationships among species. We observed that the phylogenetic tree that was obtained from the AFLP analysis had good resolution. It supported supplementary data on relationships among 14 Colchicum taxa.

NJ and MP analyses divided 14 Colchicum taxa into 3 main groups. The results of PCoA mainly corresponded to those of the NJ and MP analyses along with some inconsistencies. The analyses placed $C$. decaisnei, $C$. dolichantherum, $C$. polyphyllum, $C$. inundatum, $C$. heldreichii, and $C$. chalcedonicum far from the others, indicating a clear divergence of those species. Although C. macrophyllum was placed in a different clade in the MP tree, it was weakly supported [bootstrap (BS) value of 471]. Similar to our findings, Persson et al. (2011) reported that $C$. inundatum, $C$. heldreichii, and $C$. decaisnei were found close to each other with a clear resolution. In that study, $C$. dolichantherum was also included in the same clade, although its position was not fully resolved within the clade; however, AFLP data clearly showed the placements of those species on different branches with high support. Any relationships between the topology of analyzed species and their distribution were observed. However, all the species that were clustered in that clade were fall-blooming species, suggesting a flowering time-based grouping.

Based on sequences of 6 plastid regions, C. serpentinum was placed in a separate clade than the others (Persson et al., 2011). Similarly, it was placed on a different branch in the AFLP-based phylogenetic tree with moderate support (BS value of $542 \mathrm{BS}$ in the NJ tree and 471 in the MP tree). On the other hand, although C. serpentinum was placed on a different branch, its divergence from C. szovitsii was weakly supported in the NJ tree (BS value of 283). Supporting that, these 2 species were clustered together in the PCoA. The MP tree showed their separation with moderate support (BS value of 594). Therefore, the relationship between these species remained not fully solved.

C. kotschyi and C. speciosum were placed in an unsupported clade that was founded on the plastid region sequence analysis (Persson et al., 2011). Taking advantage of analysis of multiple loci, AFLP data successfully showed the divergence of $C$. kotschyi and C. speciosum in the NJ and MP trees with fairly high support (BS values of 889 and 866, respectively). Supporting that, the PCoA separate these 2 species.

C. balansae was found to be in the same clade as C. macrophyllum with weak support (Persson et al., 2011). Similar to the previous case, AFLP analysis depicted another ambiguous relationship between these Colchicum spp. Both species were clearly diverged from each other with very high support in both trees $(100 \%)$, which was also observed by PCoA. 
As it was discussed above, the classification of the genus Colchicum L. has always posed a great dilemma for researchers. It is hard to determine the exact phylogenetic positions of species based on 1 marker type. Each marker system has its own advantages and disadvantages. Manning et al. (2007) constructed a phylogenetic tree of Colchicum species based on combined data of $\operatorname{trn} \mathrm{L}-\mathrm{trn} \mathrm{F}$ sequences and morphology. Vinnersten and Reeves (2003) analyzed 3 DNA regions to determine the phylogeny of the same Colchicum species. Because the analysis of several regions did not produce a better resolution in that study, DNA sequence analysis remains insufficient to study the Colchicum genus. Recently, Persson et al. (2011) discussed the phylogenetic relationships of Colchicum species by analyzing 6 plastid regions. Here, we included AFLP markers to provide further resolution. Providing an opportunity to analyze multiple loci, AFLP analysis succored to species identification when sequence evaluation failed. Thus, AFLP appeared to be an appropriate method to study Colchicum species. To resolve the phylogeny of the genus Colchicum L., species should be examined based on several characteristics, such as molecular, morphological, karyological, and phytochemical characteristics. In addition, the combination of all this information should be considered in species identification.

\section{CONCLUSIONS}

Turkey and the Balkans are the major centers of diversity and speciation of the Colchicum L. genus. Genetic resources and their conservation and utilization are very important for breeding new varieties. In this study, we determined phylogenetic relationships within the genus Colchicum L. using the AFLP molecular fingerprinting method. We successfully determined the phylogenetic position of 14 Colchicum taxa. These genotypes can be used as candidates for breeding lines. With further supporting findings, our analysis presented valuable data to fill the gaps in phylogenetic relationships among Colchicum spp and improved our knowledge of Colchicum spp.

\section{ACKNOWLEDGMENTS}

Research supported by the Scientific and Technological Research Council of Turkey (TÜBİTAK), KAMAG (\#110G007).

\section{REFERENCES}

Akan H and Eker I (2005). A new record for Turkey: Colchicum crocifolium, with a contribution to the description of species. Belg. J. Bot. 138: 93-96.

Akan H and Satil F (2005). Morphological and anatomical investigations on some species of Colchicum L. occurring in south east Anatolia, Turkey. J. Biol. Sci. 5: 402-410.

Althoff DM, Gitzendanner MA and Segraves KA (2007). The utility of amplified fragment length polymorphisms in phylogenetics: a comparison of homology within and between genomes. Syst. Biol. 56: 477-484.

Baker JG (1879). A synopsis of Colchicaeae and the aberrant tribes of Liliaceae. J. Linn. Soc. Bot. 17: 405-510.

Baytop T (1999). Türkiyede Bitkiler ile Tedavi, Gecmişte ve Bugün. Nobel Tip Press, Istanbul.

Brickell CD (1984). Colchicum L. In: Flora of Turkey and the East Aegean Islands (Davis PH, ed.). Edinburgh University Press, Edinburgh, 329-351.

Buntjer JB (1997). Phylogenetic computer tools (PhylTools) version 132 for Windows. Laboratory of Plant Breeding, University of Wageningen, Wageningen. 
Castiglioni P, Pozzi C, Heun M, Terzi V, et al. (1998). An AFLP-based procedure for the efficient mapping of mutations and DNA probes in barley. Genetics 149: 2039-2056.

Çelik A, Çiçek M, Semiz G and Karincali M (2004). Taxonomical and ecological investigations on some geophytes growing around Denizli Province (Turkey). Turk. J. Bot. 28: 205-211.

Després L, Gielly L, Redoutet B and Taberlet P (2003). Using AFLP to resolve phylogenetic relationships in a morphologically diversified plant species complex when nuclear and chloroplast sequences fail to reveal variability. Mol. Phylogenet. Evol. 27: 185-196.

Doyle JJ and Doyle JL (1990). Isolation of plant DNA from fresh tissue. Focus 12: 13-15.

Düşen OD and Sümbül H (2007). A morphological investigation of Colchicum L. (Liliaceae) species in the Mediterranean region in Turkey. Turk. J. Bot. 31: 373-419.

Faccioli P, Pecchioni N, Stanca AM and Terzi V (1999). Amplified fragment length polymorphism (AFLP) markers for barley malt fingerprinting. J. Cereal Sci. 29: 257-260.

Felsenstein J (1985). Confidence limits on phylogenies: an approach using the bootstrap. Evolution 39: 783-791.

Felsenstein J (1989). PHYLIP - Phylogeny Inference Package (Version 32). Cladistics 5: 164-166.

Fitch WM (1971). Toward defining the course of evolution: minimum change for a specific tree topology. Syst. Zool. 20: 406-416.

Franková L, Cibirová K, Bilka F and Bilková A (2005). Nitrate reductase from the roots of Colchicum autumnale L. Acta Facult. Pharm. Univ. Comenianae 52: 98-107.

Fridlender A, Brown S, Verlaque R, Crosnier MT, et al. (2002). Cytometric determination of genome size in Colchicum species (Liliales, Colchicaceae) of the western Mediterranean area. Plant Cell Rep. 21: 347-352.

García-Pereira MJ, Caballero A and Quesada H (2010). Evaluating the relationship between evolutionary divergence and phylogenetic accuracy in AFLP data sets. Mol. Biol. Evol. 27: 988-1000.

Goodman LS and Gilman A (1956). The Pharmacological Basis of Therapeutics. Macmillan, New York.

Hodkinson TR, Renvoize SA, Ni-Chonghaile G, Stapleton CMA, et al. (2000). A comparison of ITS nuclear rDNA sequence data and AFLP markers for phylogenetic studies in Phyllostachys (Bambusoideae, Poaceae). J. Plant Res. 113: 259-269.

Kahraman A and Celep F (2010). Anatomical properties of Colchicum kurdicum (Bornm.) Stef. (Colchicaceae). Aust. J. Crop Sci. 4: 369-371.

Karakaş Metin O, Türktaş M, Aslay M and Kaya E (2013). Evaluation of genetic relationship between Fritillaria species from Turkey's flora using fluorescent-based AFLP. Turk. J. Biol. 37: 273-279.

Kimura M (1980). A simple method for estimating evolutionary rates of base substitutions through comparative studies of nucleotide sequences. J. Mol. Evol. 16: 111-120.

Koopman WJ, Zevenbergen MJ and Van den Berg RG (2001). Species relationships in Lactuca s.1. (Lactuceae, Asteraceae) inferred from AFLP fingerprints. Am. J. Bot. 88: 1881-1887.

Manning J, Forest F and Vinnersten A (2007). The genus Colchicum L. redefined to include Androcymbium Willd. based on molecular evidence. Taxon 56: 872-882.

Mantel N (1967). The detection of disease clustering and a generalized regression approach. Cancer Res. 27: 209-220.

Page RD (1996). TreeView: an application to display phylogenetic trees on personal computers. Comput. Appl. Biosci. 12: 357-358.

Pelletier PJ and Caventou JB (1820). Examen chimique de plusieurs végétaux de la famille des colchicées, et du principe actif qu'ils renferment. [Cévadille (Veratrum sabadilla); hellebore blanc (Veratrum album); colchique commun (Colchicum autumnale)]. Ann. Chim. Phys. 14: 69-83.

Persson K (1993). Reproductive strategies and evolution in Colchicum. Proceedings of the 5th OPTIMA Meeting, Istanbul, $397-414$.

Persson K (2000). Colchicum L. Flora of Turkey and the East Aegean Islands (Supplement II). In: 265 (Güner A, Ozhatay N, Ekim T and Baser KHC, eds.). Edinburgh University Press, Edinburgh, -246.

Persson K (2005). A new Turkish species of Colchicum (Colchicaceae) related to C. boissieri. Edinburgh. J. Bot. 62: 181-192.

Persson K (2007). Nomenclatural synopsis of the genus Colchicum (Colchicaceae), with some new species and combinations. Bot. Jahrb. Syst. 127: 165-242.

Persson K, Petersen G, Del Hoyo A, Seberg O, et al. (2011). A phylogenetic analysis of the genus Colchicum L. (Colchicaceae) based on sequences from six plastid regions. Taxon 60: 1349-1365.

Rohlf FJ (2000). NTSYS-pc numerical taxonomy and multivariate analysis system version 21. Applied Biostatistics Inc, New York.

Saitou N and Nei M (1987). The neighbor-joining method: a new method for reconstructing phylogenetic trees. Mol. Biol. Evol. 4: 406-425. 
Sambrook J, Fritsch EF and Maniatis T (1989). Molecular Cloning: A laboratory Manual. 2nd Edn. Cold Spring Harbor Laboratory, Cold Spring Harbor.

Smith RJ and Waldren S (2010). Patterns of genetic variation in Colchicum autumnale L. and its conservation status in Ireland: a broader perspective on local plant conservation. Conserv. Genet. 11: 1351-1361.

Türktaş M, Aslay M, Kaya E and Ertuğrul F (2012). Molecular characterization of phylogenetic relationships in Fritillaria species inferred from chloroplast trnL-trnF sequences. Turk. J. Biol. 36: 552-560.

Vinnersten A and Reeves G (2003). Phylogenetic relationships within Colchicaceae. Am. J. Bot. 90: 1455-1462.

$\mathrm{Xu} F$ and Sun M (2001). Comparative analysis of phylogenetic relationships of grain amaranths and their wild relatives (Amaranthus; Amaranthaceae) using internal transcribed spacer, amplified fragment length polymorphism, and double-primer fluorescent intersimple sequence repeat markers. Mol. Phylogenet. Evol. 21: 372-387.

Zhang LB, Comes HP and Kadereit JW (2001). Phylogeny and quaternary history of the European montane/alpine endemic Soldanella (Primulaceae) based on ITS and AFLP variation. Am. J. Bot. 88: 2331-2345. 